\title{
The effect of breed and stage of lactation on the microbiological status of raw milk
}

\author{
${ }^{1}$ Flóra Mária Petróczki $-{ }^{1}$ Tema Andualem Tonamo $-{ }^{2}$ Béla Béri $-{ }^{1}$ Ferenc Peles \\ ${ }^{1}$ University of Debrecen, Faculty of Agricultural and Food Sciences and Environmental Management, Institute of Food Science, Debrecen \\ ${ }^{2}$ University of Debrecen, Department of Animal Science, Debrecen \\ petroczki.flora@agr.unideb.hu
}

\begin{abstract}
SUMMARY
The microbiological quality of the milk is important not only for food safety, but it can also influence the quality of dairy products. The microbiological status of raw cow milk can be influenced by many factors. Our aim was to determine whether there was a difference between the microbiological quality of milk of two different cow breeds (Holstein Friesian and Jersey) kept and milked in the same conditions, and how the microbiological quality of the raw cow milk changed during lactation (beginning, mid, and end). Samples were taken and analysed in July, August and September in 2018 from two dairy farms in Hajdu-Bihar county. During the conducted studies, the total plate count (TPC), the coliform count, the Staphylococcus aureus count and the coagulase-negative Staphylococcus (CNS) count of raw milk samples were determined.

There was no significant difference $(P>0.05)$ between the milk of the Holstein Friesian and Jersey breeds in the case of TPC. However, the mean coliform count of milk samples taken from Holstein Friesian cows was significantly lower $(P<0.05)$ than the mean coliform count of milk samples taken from Jersey cows. S. aureus was detected in one of the twelve milk samples taken from Holstein Friesian cows, and in two of the eleven milk samples taken from Jersey cows. CNS was found in larger amount in milk samples taken from Holstein Friesian cows, and the difference was significant $(P<0.05)$. Both TPC and CNS count were significantly higher $(P<0.05)$ in individual milk samples taken at the end stage of lactation, than in samples taken in the earlier stages of lactation from Farm " $A$ ”. However, in the case of Farm " $B$ ”, there was no significant difference $(P>0.05)$ in colony counts at different stages of lactation. S. aureus was only present in milk samples that collected from cows, which were at the beginning and middle stages of lactation. Testimg the hemolysin production ability of $S$. aureus strains isolated from the raw milk samples, only weak hemolysis was observed on blood agar. In case of antibiotic resistance testing, it was found that all strains were susceptible to cefoxitin, chloramphenicol, clindamycin, erythromycin, gentamicin, penicillin G, tetracycline and trimethoprim/sulphamethoxazole.

Based on the results of our studies, staphylococci were detected in a higher amount in the milk of Holstein Friesian cows, and coliform bacteria were detected in a higher number in the milk of Jersey cows. Summing up the results of the milk samples taken from the different stages of lactation in one of the farms, it can be concluded that higher TPC and CNS count could be detected at the end stage of lactation than in the samples taken from the earlier stages of lactation. The fact that at the end of lactation the microorganisms could be detected in a higher colony count may be related to the fact that teats could be damaged during lactation by the milking machine, which increased the chance of imvading the microorganisms into the udder.
\end{abstract}

Keywords: microbiological quality, raw milk, Holstein Friesian, Jersey, stage of lactation, Staphylococcus aureus

\section{INTRODUCTION}

Milk contains several nutrients important for the human body, for example proteins, fats, vitamins, minerals and water (Haug et al., 2007). These nutrients are also necessary for microorganisms; therefore, many microorganisms can be present in the milk, including pathogenic organisms, e.g. Staphylococcus aureus (Normanno et al., 2007; Huong et al., 2010). In addition, the high water activity and neutral $\mathrm{pH}$ of the milk provide optimal conditions to their growth (Quigley et al., 2011). The milk of a healthy cow contains few microorganisms. But during handling of milk after milking it can easily be contaminated (Biró, 2014). Contamination may occur for example from the skin of the animals, from the environment or from milking machines, milk lines and storage tanks. Mostly, heat treatment is used to reduce the number of bacteria. The initial microbiological quality of the milk is important not only for food safety, but it can also influence the quality of the dairy products (Cilliers et al., 2014). The Codex Alimentarius Hungaricus Directive Number 2-51 (2004) contains requirements for milk and dairy products. According to it, for the manufacture of dairy products the materials should meet the relevant requirements, national recommendations, commercial requirements and dietary goals.

Milk can be contaminated with microorganisms within the udder. Improperly used, misconfigured milking equipment can have an adverse effect on teats, teat canal and mucous membrane. By damaging the primary defense line of the udder, the protection against microorganisms ceases (Tóth, 2015). These pathogens are usually prevented from getting into the udder by the many protection mechanisms of the teat canal (Paduch et al., 2012). Zecconi et al. (2009), however, concluded that milking machine induced changes in the teat are predisposing factors to environmental pathogens to colonize the teat canal, which could contribute to the development of mastitis.

Mastitis pathogens can be for example coliform bacteria, S. aureus, and also coagulase-negative Staphyloccoccus (Pyörälä and Taponen, 2009). The importance of coliform mastitis lies in the fact that milk production can be significantly reduced, causing economic losses to dairy farms (Mbuk et al., 2016). For about a century, the coliform bacteria have been used 
as indicator microorganisms (Tortorello, 2003). As they are generally present in the environment, their presence in food may indicate environmental contamination (Altalhi and Hassan, 2009; Mhone et al., 2011). These bacteria are gram-negative, have aerobic or facultative anaerobic properties and do not produce spores. They can ferment lactose, while they produce acid and gas (Rompré et al., 2002). Coliform bacteria can be present in the dairy farm environment, for example in water, plant materials, equipment, dirt or in fecal sources (Kagkli et al., 2007).

Milk provides excellent conditions for the growth of Staphylococci and their production of enterotoxin (Korpysa-Dzirba and Osek, 2011). Enterotoxins produced by enterotoxin-producing $S$. aureus strains can cause food poisoning in people who consume food contaminated with this bacteria (Jørgensen et al., 2005). The symptoms (diarrhea, vomiting, abdominal cramps) appear 1 to 8 hours after the contaminated food is consumed (Korpysa-Dzirba and Osek, 2011). In dairy farms, raw milk may be contaminated with the bacteria from the environment, from the hands of the milkers and from the milking equipment (Rosengren et al., 2010). S. aureus is a cause of mastitis in dairy farms. In the case of dairy cows, $S$. aureus causes $5-30 \%$ of clinical mastitis, and $5-10 \%$ of subclinical mastitis (Peton and Loir, 2014). The economic significance of mastitis caused by $S$. aureus lies in the fact that the amount of milk decreases because of the mastitis, and the quality of the milk decreases because of the higher somatic cell counts, so the milk price income decreases (Ózsvári et al., 2003).

The importance of coagulase-negative Staphylococcus (CNS) as a mastitis pathogen is not negligible. Mastitis caused by CNS is mainly subclinical, but sometimes it may also cause clinical symptoms. CNS may cause persistent infections, can increase somatic cell count (SCC) in milk, and may also result in a decrease in milk production (Pyörälä and Taponen, 2009).

The microbiological quality of raw cow's milk can be influenced by numerous external and internal factors. It is largely determined by the cleanliness of surfaces which contact with milk (milking machine, milking tank, etc.) (Anderson et al., 2003). Peles et al. (2008), studying the bulk milk of different size dairy farms using different animal keeping and milking methods in their study, found that these factors influence the microbiological quality of milk. The microbiological quality of the milk may also vary in the different stages of lactation. During their investigations, Tona et al. (2016), experienced an increase in colony counts towards the end of lactation of jersey cows. Milking with the milking machine may have a damaging effect on the teat and may deliver bacteria from the environment to the udder (Hamann et al., 1993). Tessema (2016), however, concluded in his study that there was no significant difference in occurrence of $S$. aureus at various stages of lactation.

According to Nóbrega and Langoni (2011), there can be differences in immune responses between Jersey and Holstein Friesian breeds. In their study, environmental pathogens were more frequently isolated from the milk of Jersey cows than the milk of Holstein Friesian cows. The authors, however, attributed their results to the fact that the average lactation number of Jersey cows was higher than the average lactation number observed in Holstein Friesian cows, which could be related to the damage of the teats and the decreasing functionality of the sphincter of the udder. Based on the results of the authors, the question arises, whether there is a difference between the microbiological status of the milk produced by the two cow breeds. Tessema (2016) also dealt with this topic in their study and observed a significant difference between two cow breeds (cross, local) in the presence of $S$. aureus in milk, however, the occurrence of $S$. aureus was higher in cross breeds in the case of older cows. Bytyqi et al. (2013), however, observed no significant difference between the colony count in the raw milk of different cow breeds.

Therefore, in our investigations, we aimed to determine whether there is a difference between the microbiological quality of the milk of different cow breeds (Holstein Friesian, Jersey) milked and kept in the same conditions and how the microbiological status of raw cow milk varies in different stages of lactation (beginning, mid, end).

\section{MATERIAL AND METHODS}

\section{Place and date of sampling}

Two dairy farms (Farm „A” and Farm „B”) in Hajdú-Bihar county (Hungary) were involved in our investigations. There are 670 lactating cows of different ages and lactation numbers in Farm „A”, which are Holstein Friesian and Jersey cows. In the farm cubicle loose is used as keeping method and TMR (Total Mixed Ration) feeding has been applied. Milking is done in milking parlour. Pre-and post-milking disinfection are also used during milking. On the Farm "B", 450 Holstein Friesian cows are milked, and unlike Farm "A", deep litter is used as keeping method. Another difference is that after the milking, Farm "B" does not perform post-milking disinfection. Milking is also done in milking parlour.

Our microbiological examinations were conducted between July and September 2018, and during this period, sampling was done two times in Farm "A", and one time in Farm "B". On both occasions in Farm „A", 6-6 Holstein Friesian and Jersey cows were sampled, of which $2-2$ individuals were in the early (0-100 days) stage of their first lactation, 2-2 individuals were in the middle of their first lactation (100-200 days), and 2-2 individuals were in the late stages of their first lactation (200-300 days). During one sampling, we had the opportunity to collect milk sample from only one Jersey individual which was in late stages in it's first lactation. The keeping, milking and the feeding method were the same in the case of all individuals and the two sampling were done during the same time of the day (during afternoon milking) in summer in dry weather conditions. So it can be assumed that these "non-breedrelated factors" did not significantly affect the 
microbiological quality of raw milk from the two breeds. Nine Holstein Friesian cows were sampled in Farm "B". Three of them were in the early (0-100 days) stage of their first lactation, three were in the middle of their first lactation (100-200 days), and finally three individuals were in the late stages of their lactation (200-300 days).

For microbiological studies, raw milk samples of individual cows were collected in sterile plastic sample containers. The sampling was performed individually and from all four udder quarters, following disinfection and drying of the teats. After sampling, the samples collected in sterile tubes were delivered within two hours in a cooler bag equipped with ice batteries to the Microbiological Laboratory of the Institute of Food Science at the University of Debrecen, where the samples were processed as soon as possible.

\section{Microbiological analysis}

Samples were stored and diluted according to the MSZ EN ISO 6887-1 (2000) standard. Milk samples were stored in refrigerator (on $4{ }^{\circ} \mathrm{C}$ ) until testing, and homogenized by shaking before the decimal dilutions were done. To prepare the decimal dilution line, $9 \mathrm{ml}$ of the peptone water was put in test tubes, which were then sterilized in pressure cooker for 30 minutes at about $120{ }^{\circ} \mathrm{C}$. Peptone water was contained $8.5 \mathrm{~g}$ of sodium chloride (VWR International Ltd., Hungary) and $1.0 \mathrm{~g}$ of peptone (Merck Kft., Hungary), and were dissolved in distilled water, then sterilized.

Microbiological tests were performed according to standards for the microorganisms. The total plate count (TPC) was performed according to the MSZ EN ISO 4833-1 (2014) standard. Plate count agar (PCA) (Biolab Ltd., Hungary) supplemented with milk powder (1 $\mathrm{g}$ in $1000 \mathrm{ml}$ media) was used and the determination was done by pour plate technique. When preforming the pour plate technique, $1 \mathrm{ml}$ from the dilution was pipetted into sterile plastic Petri dishes, then we poured the medium on it and mixed. Following the solidication, plates were incubated at $30{ }^{\circ} \mathrm{C}$ for 72 hours.

The determination of the coliform count was carried out in accordance with the ISO 4832 (2006) standard. Sterile Violet Red Bile Lactose (VRBL) agar (Biolab Ltd., Hungary) was used and the test was done by pour plate technique. The inkubation lasted at $37^{\circ} \mathrm{C}$ for 24 hours.

The $S$. aureus count was determined by spread plate method, in accordance with the MSZ EN ISO 6888-1 (2008) standard. Baird-Parker agar (BPA) (Biolab Ltd., Hungary) was used supplemented with egg yolk tellurit emulsion (LAB-KA Ltd., Hungary), and the plates were incubated at $37^{\circ} \mathrm{C}$ for 48 hours. When performing the spread plate technique, $0.1 \mathrm{ml}$ of the dilutions was pipetted onto the medium and then spread by a sterile glass rod. S. aureus was identified with latex agglutination test kit (Prolex Staph Xtra Kit, Ferol Ltd., Hungary). Hemolysis tests of isolated S. aureus strains were performed on Columbia Blood Agar (Biolab Ltd., Hungary). The inoculated media were incubated at 37 ${ }^{\circ} \mathrm{C}$ for 24 hours.
The antibiotic resistance test of the isolated strains was performed by agar diffusion method according to the Clinical and Laboratory Standards Institute guidelines (2017). During the test, the bacterial suspension adjusted to $0.5 \mathrm{McF}$ arland was spreaded on Mueller-Hinton Agar (Biolab Ltd., Hungary) with sterile cotton swab, and then the antibiotic-soaked paper disks were placed on the surface of the inoculated media. Incubation was performed at $35{ }^{\circ} \mathrm{C}$ for 18 hours. The following antibiotic disks were used for the study: cefoxitin (30 $\mu \mathrm{g} / \mathrm{disk})$, chloramphenicol (30 $\mu \mathrm{g} / \mathrm{disk})$, clindamycin (2 $\mu \mathrm{g} / \mathrm{disk})$, erythromycin (15 $\mu \mathrm{g} / \mathrm{disk})$, gentamicin (10 $\mu \mathrm{g} /$ disk), penicillin G (10U), tetracycline (30 $\mu \mathrm{g} /$ disk), trimethoprim/sulphamethoxazole $(1.25+23.75 \mu \mathrm{g} / \mathrm{disk})$ (Biolab Ltd., Hungary).

\section{Statistical analysis}

Calculation of averages, standard deviations (SD), logarithmic transformation of the amount of microorganisms, t-tests and variance analysis were performed using the SPSS v.22.0 (SPSS 2013) software.

\section{RESULTS AND DISCUSSION}

\section{The effect of breed on the microbiological status of raw milk}

Comparison of the microbiological quality of the raw milk from the two studied breeds was possible only in Farm „A". In individual raw milk samples taken from Holstein Friesian and Jersey cows, the mean TPC were 3.5 $\pm 0.6 \log _{10} \mathrm{CFU} / \mathrm{ml}$ and $3.4 \pm 0.5 \log _{10} \mathrm{CFU} / \mathrm{ml}$, respectively. The mean TPC of individual raw milk samples taken from Holstein Friesian cows was higher than the mean TPC of raw milk samples taken from Jersey cows (Figure 1) but the difference was not significant $(\mathrm{P}>0.05)$.

In the milk samples from Holstein Friesian cows, the mean coliform count was $0.7 \pm 0.4 \log _{10} \mathrm{CFU} / \mathrm{ml}$, and in Jersey individual raw milk samples it was $1.0 \pm 0.4 \log _{10} \mathrm{CFU} / \mathrm{ml}$. The mean coliform count of milk samples taken from Holstein Friesian cows was lower than the mean coliform count of milk samples taken from Jersey cows (Figure 1). The difference was significant $(\mathrm{P}<0.05)$.

Of the 12 raw milk samples taken from Holstein Friesian cows, only one sample contained $S$. aureus. The mean $S$. aureus count of the sample was $3.9 \log _{10}$ $\mathrm{CFU} / \mathrm{ml}$. Of the 11 raw milk samples collected from Jersey cows, two samples contained $S$. aureus and the mean colony count was $3.1 \pm 0.5 \log _{10} \mathrm{CFU} / \mathrm{ml}$. The mean $S$. aureus count of the samples of Jersey cows was lower than the colony count detected in the case of the Holstein Friesian cow.

In the raw milk samples taken from Holstein Friesian and Jersey cows, the mean CNS count were $3.6 \pm 0.4 \log _{10} \mathrm{CFU} / \mathrm{ml}$ and $3.4 \pm 0.4 \log _{10} \mathrm{CFU} / \mathrm{ml}$, respectively. Again, lower colony counts were detected in milk samples taken from Holstein Friesian cows (Figure 1), and the difference was significant $(\mathrm{P}<0.05)$. 
In case of all microbiological parameters tested, except for the coliform count, higher colony counts were obtained in the milk of Holstein Friesian breed. While, in the case of TPC there was no significant difference between the colony counts in the milk of the two breeds, but there was a significant difference in the case of coliform count, $S$. aureus count and CNS count. Bytyqi et al. (2013) observed no significant difference between the colony count in the raw milk of different cow breeds.

Figure 1: Microbiological quality of raw milk from Holstein Friesian and Jersey breeds

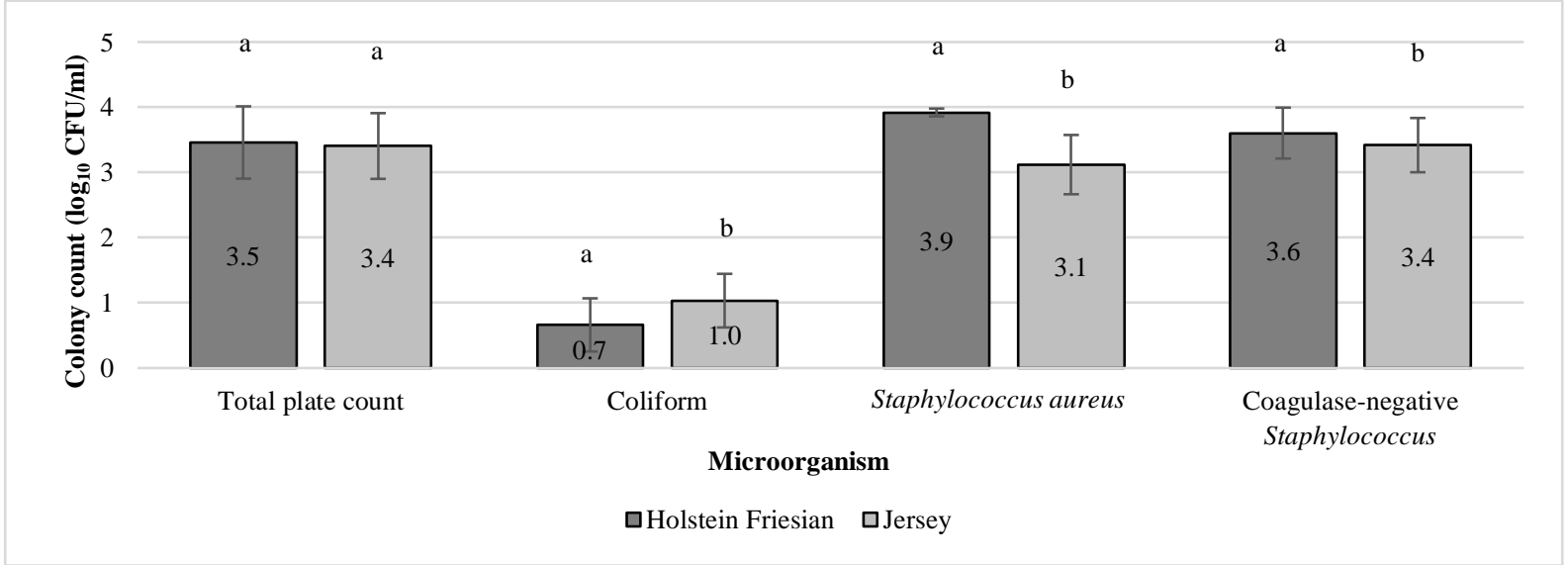

The effect of stage of lactation on the microbiological status of raw milk

The TPC of raw cow milk samples taken at Farm „A" at different stages of lactation was determinated. The mean TPC in milk samples taken at the early stage of lactation was $3.3 \pm 0.6 \log _{10} \mathrm{CFU} / \mathrm{ml}$, while it was $3.3 \pm 0.4 \log _{10} \mathrm{CFU} / \mathrm{ml}$ in milk samples taken in the middle stage of lactation, and $3.7 \pm 0.5 \log _{10} \mathrm{CFU} / \mathrm{ml}$ in

milk samples taken at the end stage of lactation (Figure 2). In our study, the mean TPC detected in milk samples taken at the end of lactation was significantly $(\mathrm{P}<0.05)$ higher than in the milk samples taken at the beginning and at the middle stages of lactation. Similar conclusion was published by Tona et al. (2016), who had found in their investigations that the TPC was increased during lactation in milk taken from Jersey breed.

Figure 2: Microbiological status of raw milk in different stages of lactation in Farm „A”

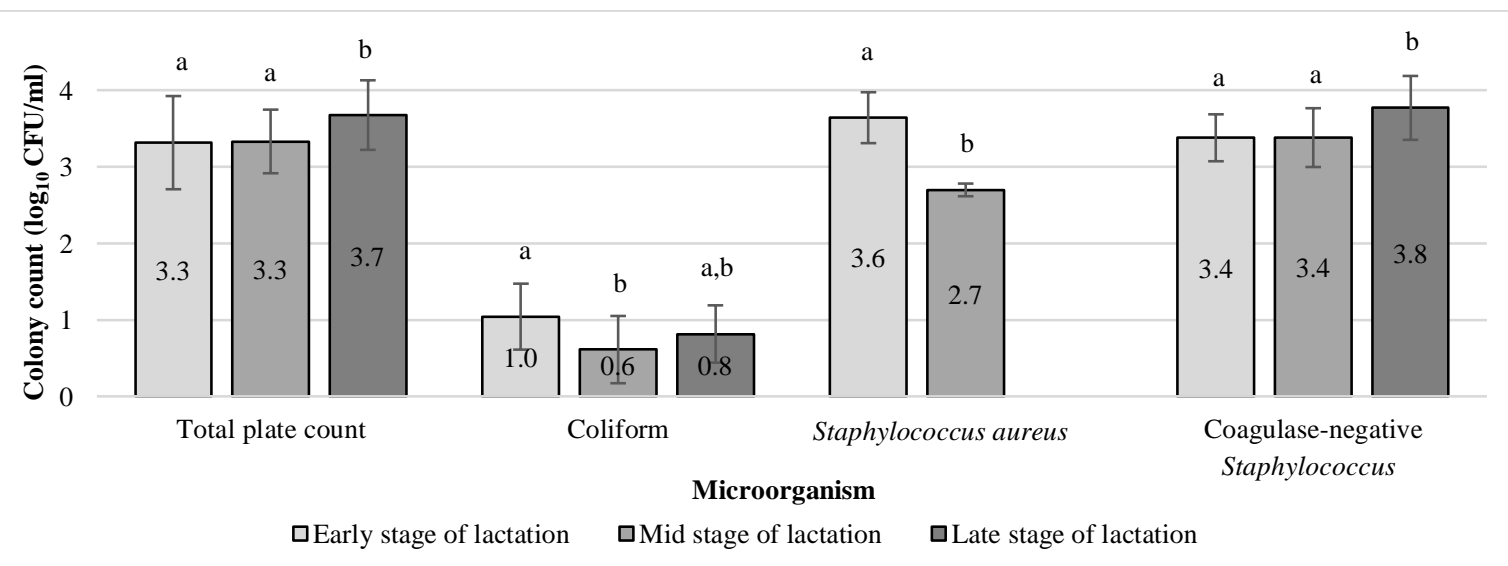

The highest mean coliform count $\left(1.0 \pm 0.4 \log _{10}\right.$ $\mathrm{CFU} / \mathrm{ml}$ ) was detected in raw milk samples taken at the beginning stage of lactation, and the lowest $(0.6 \pm 0.4$ $\left.\log _{10} \mathrm{CFU} / \mathrm{ml}\right)$ in the samples from the middle stage of lactation. The difference was significant $(\mathrm{P}<0.05)$. Tona et al. (2015) did not detected coliform bacteria in milk taken in early and middle stages of lactation milk samples of dairy cows, but the coliform count was 2.4 $\log _{10} \mathrm{CFU} / \mathrm{ml}$ in the milk from cows in late stage of lactation, with a higher values than in our study.

$S$. aureus were detected in the milk of only three cows in excess of $1.0 \log _{10} \mathrm{CFU} / \mathrm{ml}$, of which 2 cows 
were at the beginning stage of lactation when sampling occurred and 1 cow was in the middle stage of lactation. The mean $S$. aureus count was higher in the samples taken at the beginning stage of lactation $\left(3.6 \pm 0.3 \log _{10}\right.$ $\mathrm{CFU} / \mathrm{ml}$ ) than in the sample taken in the middle stage of lactation $\left(2.7 \pm 0.1 \log _{10} \mathrm{CFU} / \mathrm{ml}\right)$. Waller et al. (2009) investigated the distribution of the most common bacterial infections in the different stages of lactation in milk samples taken from individuals with clinical mastitis. Based on their results, S. aureus occurred in a higher rate in milk during the first month of lactation than in later stages of lactation.

CNS count in raw milk samples was significantly lower $(\mathrm{P}<0.05)$ in the samples taken at the beginning and middle stages of lactation $\left(3.4 \pm 0.3 \log _{10} \mathrm{CFU} / \mathrm{ml}\right.$, $\left.3.4 \pm 0.4 \log _{10} \mathrm{CFU} / \mathrm{ml}\right)$ than in the samples taken at the final stage of lactation $\left(3.8 \pm 0.4 \log _{10} \mathrm{CFU} / \mathrm{ml}\right)$. Waller et al. (2009) also found, that at the end of lactation, CNS occurred in a higher rate than at the beginning and middle stages of lactation.

TPC was also deretmined in the raw milk samples taken at different stages of lactation at Farm „B”. The mean colony count were $3.3 \pm 0.3 \log _{10} \mathrm{CFU} / \mathrm{ml} ; 3.3 \pm 0.5$ $\log _{10} \mathrm{CFU} / \mathrm{ml}$ and $3.4 \pm 0.3 \log _{10} \mathrm{CFU} / \mathrm{ml}$, in milk samples taken at the beginning, middle and late stages of lactation respectively. As in the case of Farm „A", an increasing tendency in TPC towards the end of lactation could be observed also in Farm „B”, as shown in Figure 3, but there is no significant difference $(\mathrm{P}>0.05)$ in the case of Farm ,B”.

At Farm „B” the highest mean coliform count was obtained in raw milk samples taken from cattles in the middle stage of lactation, and the lowest value were in the samples from cows at the end stage of lactation. The mean coliform count was $1.0 \pm 0.3 \log _{10} \mathrm{CFU} / \mathrm{ml}$ in the samples taken at the beginning stage of lactation, while in the middle stage of lactation it was $1.3 \pm 0.8 \log _{10}$ $\mathrm{CFU} / \mathrm{ml}$ and $0.9 \pm 0.6 \log _{10} \mathrm{CFU} / \mathrm{ml}$ at the end stage of lactation it was. The difference between the above values was not significant $(\mathrm{P}>0.05)$.

S. aureus was detected in less than $1.0 \log _{10} \mathrm{CFU} / \mathrm{ml}$ values in individual milk samples taken from Farm ,B”.

An increase in the number of colonies was observed in the different lactation stages, when enumerating the CNS count in raw milk samples taken from Farm „B”, but there was no significant difference $(\mathrm{P}>0.05)$ between them. The mean CNS count in the raw milk samples was $3.1 \pm 0.2 \quad \log _{10} \mathrm{CFU} / \mathrm{ml}$ taken at the beginning stage of lactation, $3.1 \pm 0.3 \log _{10} \mathrm{CFU} / \mathrm{ml}$ in the samples from middle stage of lactation, and 3.2 \pm 0.4 $\log _{10} \mathrm{CFU} / \mathrm{ml}$ at the end.

Figure 3: Microbiological status of raw milk in different stages of lactation in Farm „B”

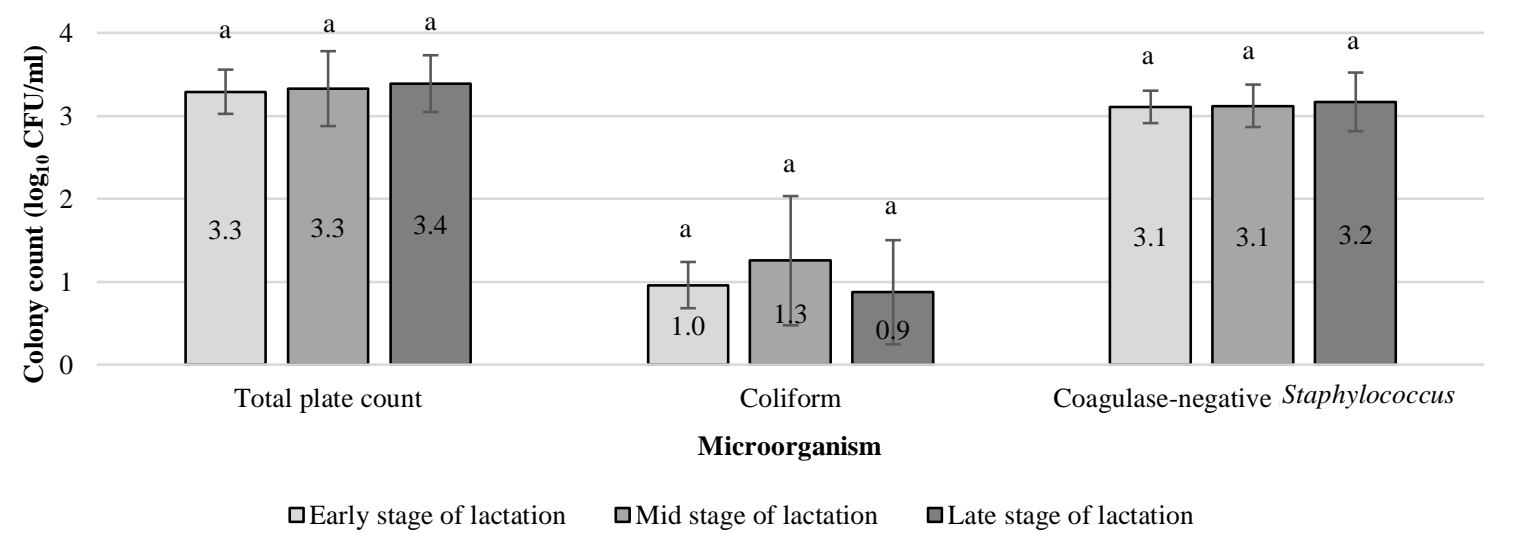

The effect of breed and stage of lactation on the microbiological status of raw milk

The effect of breed and stage of lactation on the microbiological status of milk was studied in the case of samples taken at Farm "A". The mean colony count (TPC) in the samples taken from the beginning stage of lactation was $3.2 \pm 0.6 \log _{10} \mathrm{CFU} / \mathrm{ml}$, in the samples taken from the middle stage of lactation it was $3.4 \pm 0.5$ $\log 10 \mathrm{CFU} / \mathrm{ml}$ and in the samples taken at the end stage of lactation it was $3.8 \pm 0.5 \log _{10} \mathrm{CFU} / \mathrm{ml}$ from the raw milk samples of Holstein Friesian cows (Figure 4). There was a significant difference $(\mathrm{P}<0.05)$ between the mean TPC in the samples taken from the beginning and end stages of lactation. In the case of Jersey cows, the mean TPC was higher in the samples taken from the cows in end stage of lactation of $\left(3.5 \pm 0.4 \log _{10}\right.$ $\mathrm{CFU} / \mathrm{ml}$ ), than in the samples taken from the beginning and middle stages of lactation $\left(3.4 \pm 0.6 \log _{10} \mathrm{CFU} / \mathrm{ml}\right.$, $\left.3.3 \pm 0.4 \log _{10} \mathrm{CFU} / \mathrm{ml}\right)$, but the difference was not significant $(\mathrm{P}>0.05)$. Comparing the TPC detected in raw milk of the two breeds in the different stages of lactation, there were no significant difference ( $\mathrm{P}>0.05)$., Tona et al. (2015) had similar conclusion in their microbiological studies of milk of Jersey cows in their study of the effect of lactation on microbiological status of raw milk. 
Figure 4: Mean total plate count in raw milk of Holstein Friesian and Jersey breeds in different stages of lactation

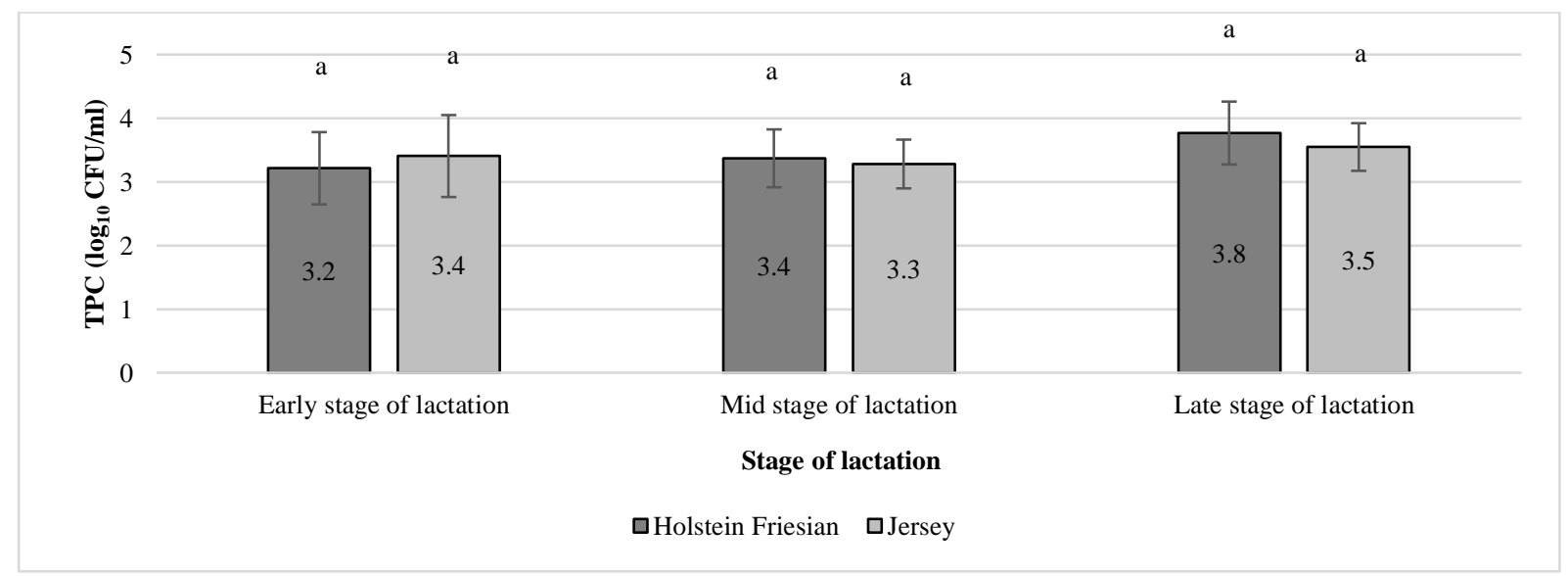

The highest mean coliform counts $\left(0.7 \pm 0.4 \log _{10}\right.$ $\mathrm{CFU} / \mathrm{ml}, 1.3 \pm 0.3 \log _{10} \mathrm{CFU} / \mathrm{ml}$ ) were detected in raw milk taken at the beginning stage of lactation, and the mean coliform counts $\left(0.6 \pm 0.5 \log _{10} \mathrm{CFU} / \mathrm{ml} ; 0.6 \pm 0.4\right.$ $\log _{10} \mathrm{CFU} / \mathrm{ml}$ ) were detected in the lowest amount in the samples taken from middle stage of lactation in the case of Holstein Friesian and Jersey breeds. In the case of Jersey breed, significant difference $(\mathrm{P}<0.05)$ was observed in mean coliform count in the milk samples taken at the beginning and the middle stages of lactation. At each of the three lactation stages, a higher number of coliform bacteria was detected in the milk samples taken from the Jersey cows (Figure 5).

Figure 5: Mean coliform count in raw milk of Holstein Friesian and Jersey breeds in different stages of lactation

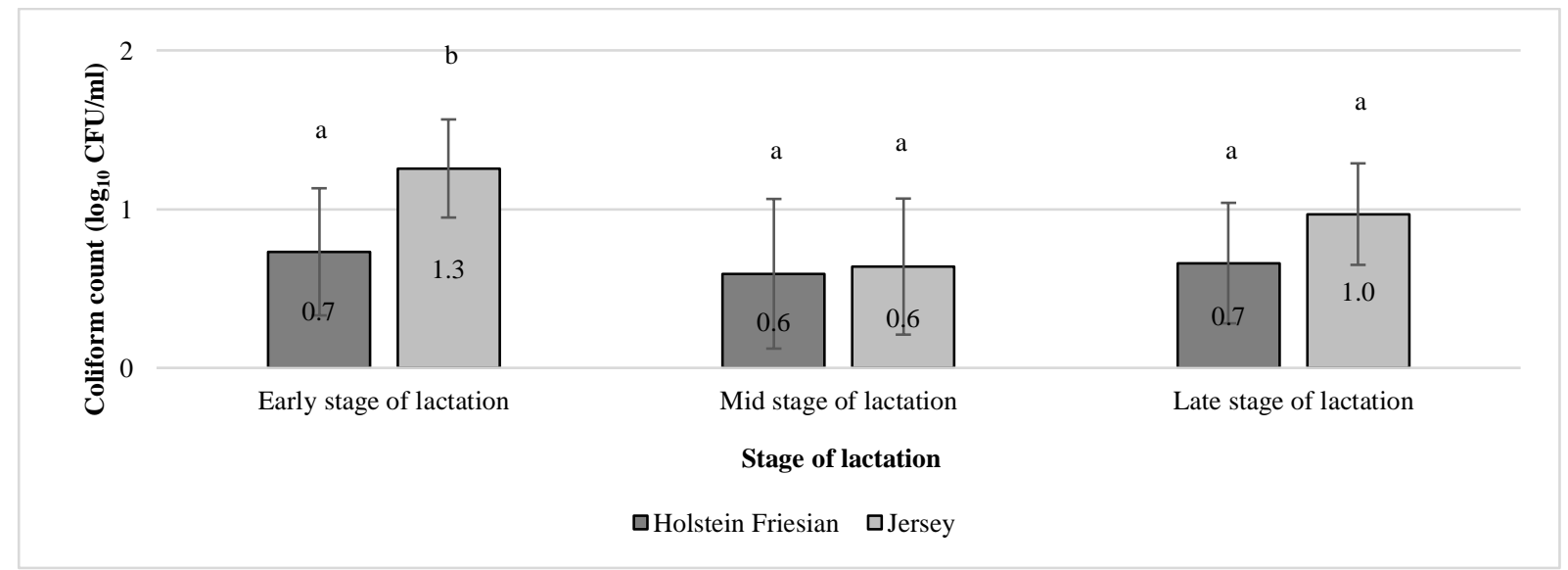

S. aureus occurred in raw milk of only one Holstein Friesian cow and raw milk of 2 Jersey cows, in greater amount than $1.0 \log _{10} \mathrm{CFU} / \mathrm{ml}$.

The mean colony count of CNS in the samples taken from the beginning stage of lactation was $3.4 \pm 0.3 \log _{10}$ $\mathrm{CFU} / \mathrm{ml}$ in the case of count Holstein Friesian cows, while it was $3.4 \pm 0.3 \log _{10} \mathrm{CFU} / \mathrm{ml}$ in the samples taken from the middle stage of lactation, and $3,9 \pm 0.4 \log _{10}$ $\mathrm{CFU} / \mathrm{ml}$ in the samples taken at the end stage of lactation it was (Figure 6). Significant difference $(\mathrm{P}<0.05)$ was observed in the CNS count in the milk samples taken at the beginning and middle stages of lactation and in the milk samples taken at the end stage of lactation. In the case of Jersey breed, the mean CNS count was higher in the samples collected at the end stage of lactation $\left(3,6 \pm 0,5 \log _{10} \mathrm{CFU} / \mathrm{ml}\right)$ than in the samples from the beginning and middle stages of lactation $\quad\left(3.3 \pm 0.3 \quad \log _{10} \quad \mathrm{CFU} / \mathrm{ml}, \quad 3.3 \pm 0.5 \quad \log _{10}\right.$ $\mathrm{CFU} / \mathrm{ml}$ ), but the difference was not significant $(\mathrm{P}>0.05)$. At each of the three lactation stages, a higher amount of CNS was detected in the milk samples from the Holstein Friesian breed, but no significant difference $(\mathrm{P}>0.05)$ was observed. 

lactation

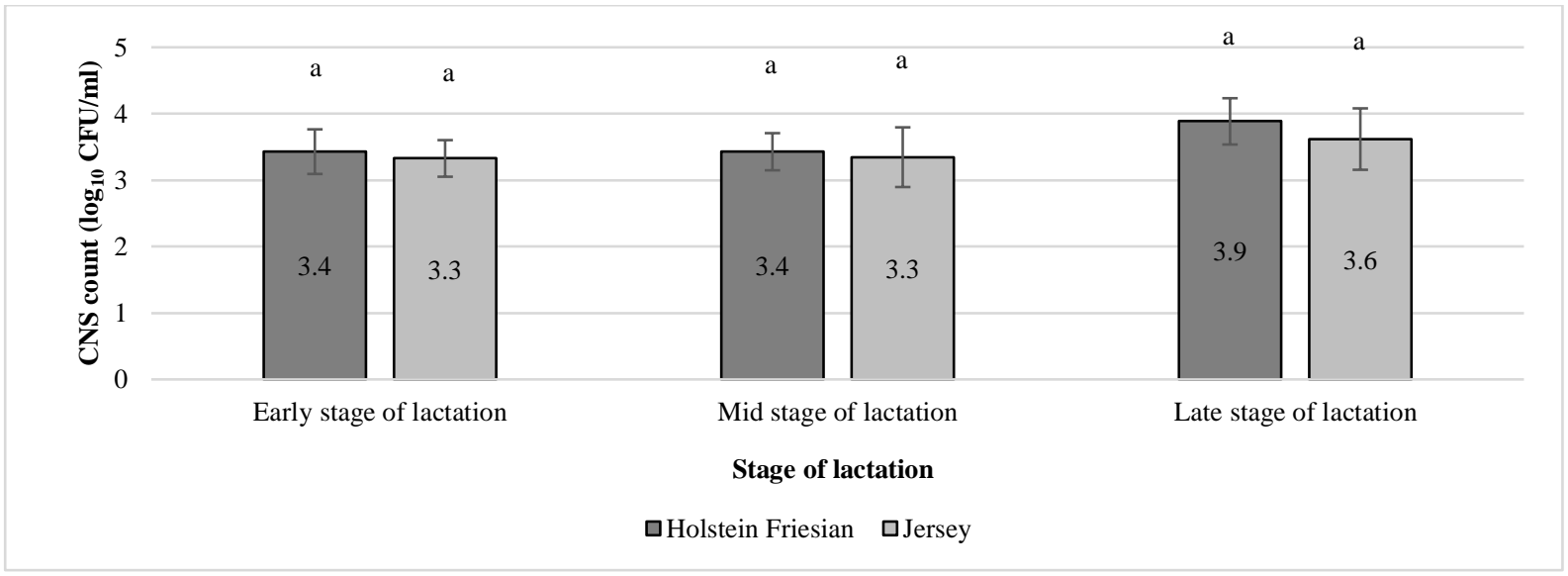

Characteristics of $S$. aureus strains isolated from cow individual raw milk

In our studies, S. aureus occurred only in one of the two studied farms (Farm „A") in the raw milk samples from three cows. From all three samples 1-1 isolates were selected for further testing. Each strain had black color on the Baird-Parker agar medium supplemented with egg yolk tellurit emulsion, that is the tellurit was reduced to tellurium by the bacteria. The strains did not possess lecithinase activity, because no clear zone around the colonies was observed. Weak hemolysis was observed on blood agar in the case of all three strains. All three strains were susceptible to all tested antibiotics. Similarly, the strains studied by Visciano et al. (2014) were susceptible to gentamicin and the strains studied by Peles et al. (2007), were susceptible to cefoxitin, erythromycin, tetracycline, trimethoprim/sulphamethoxazole. Many authors have examined the antibiotic resistance of $S$. aureus strains that can be isolated from raw cow milk, and the results were highly varied. For example, while the occurrence of penicillin-resistant strains in the study of Peles et al. (2007) and Visciano et al. (2014) was 30.5\% and $41 \%$ respectively, André et al. (2008) found that $70.8 \%$ of the strains they tested were resistant to penicillin.

\section{CONCLUSIONS}

In the case of all tested microbiological parameters, higher colony counts were obtained in the milk of Holstein Friesian breed, except for the coliform count. While, in the case of TPC there was no significant difference between the colony counts in the milk of the two breeds, but there was a significant difference in the case of coliform count, S. aureus count and CNS count.

Summarizing the results of the samples taken at different stages of lactation at the Farm „A”, it can be concluded that the TPC and the CNS count was significantly higher in the milk samples taken at the end of lactation than samples taken at the beginning and the middle of lactation, i.e., the stage of lactation affected these microbiological parameters. The results coincide with Tona et al. (2015), who also found that, the TPC was higher in the individual cow milk collected at the end of lactation; and Waller et al. (2009), who found CNS was higher in milk at the end of lactation, than in earlier stages of lactation. The fact that, at the end of lactation, microorganisms can be detected in a higher colony count in milk may be related to the fact that the teats may be injured during lactation by milking machines, and this may increase the chance of the microorganisms to get into the udder. Appropriate use and adjustment of milking machines is recommended to reduce the amount of bacteria in raw milk. However, there was no significant difference in colony counts in milk samples taken from different stages of lactation in the case of the other studied farm (Farm „B”). So it can be said that on Farm „B”, the milking machines do not cause damage on the cows' teats.

In our study, none of the tested isolates were resistant to any antibiotics studied. The continuous monitoring of the antibiotic sensitivity and profile of microorganisms can be useful for treating infections more effectively and reducing the development of antibiotic-resistant microorganisms.

\section{ACKNOWLEDGEMENTS}

The work/publication is supported by the EFOP3.6.3-VEKOP-16-2017-00008 project. The project is co-financed by the European Union and the European Social Fund. 


\section{REFERENCES}

Altalhi, A. D.-Hassan, S. A. (2009): Bacterial quality of raw milk investigated by Escherichia coli and isolates analysis for specific virulence-gene markers. Food Control. 20.913-917.

Anderson, D.-Dulmage, D.-McDougall, M.-Séguin, G. (2003): General guidelines for effective dairy equipment cleaning.

André, M. C. D. P. B.-Campos, M. R. H.-Borges, L. J.-Kipnis, A.Pimenta, F. C.-Serafini, Á. B. (2008): Comparison of Staphylococcus aureus isolates from food handlers, raw bovine milk and Minas Frescal cheese by antibiogram and pulsed-field gel electrophoresis following SmaI digestion. Food Control. 19. 200-207.

Biró, G. (2014): Élelmiszer-higiénia. Agroinform Kiadó, Budapest. 530. p.

Bytyqi, H.-Vehapi, I.-Rexhepi, S.-Thaqi, M.-Sallahi, D.-Mehmeti, I. (2013): Impact of Bacterial and Somatic Cells Content on Quality Fresh Milk in Small-Scale Dairy Farms in Kosovo. Food and Nutrition Sciences. 4. 1014-1020.

Cilliers, F. P.-Gouws, P. A.-Koutchma, T.-Engelbrecht, Y.Adriaanse, C.-Swart, P. (2014): A microbiological, biochemical and sensory characterisation of bovine milk treated by heat and ultraviolet (UV) light for manufacturing Cheddar cheese. Innovative Food Science and Emerging Technologies. 23. 94 106.

Clinical Laboratory Standards Institute (CLSI) (2017): Performance standards for antimicrobial susceptibility testing. M100, 27th ed. CLSI, Wayne, PA.

Codex Alimentarius Hungaricus Regulation Number 2-51 (2004) Tej és tejtermékek. Magyar Élelmiszerkönyv Bizottság.

Hamann, J.-Mein, G. A.-Wetzel, S. (1993): Teat tissue reactions to milking: effects of vacuum level. Journal of Dairy Science. 76. 1040-1046.

Haug, A.-Høstmark, A. T.-Harstad, O. M. (2007): Bovine milk in human nutrition - a review. Lipids in Health and Disease. 6. 25.

Huong, B. T. M.-Mahmud, Z. H.-Neogi, S. B.-Kassu, A.-Nhien, N. V.-Mohammad, A.-Yamato, M.-Ota, F.-Lam, N.T.-Dao, H. T. A.-Khan, N. C. (2010): Toxigenicity and genetic diversity of Staphylococcus aureus isolated from Vietnamese ready-to-eat foods. Food Control. 21. 166-171.

ISO 4832 (2006): Microbiology of food and animal feeding stuffs Horizontal method for the enumeration of coliforms - Colonycount technique.

Jørgensen, H. J.-Mørk, T.-Caugant, D. A.-Kearns, A.-Rørvik, L. M. (2005): Genetic Variation among Staphylococcus aureus Strains from Norwegian Bulk Milk. Applied and Environmental Microbiology. 71. 12.8352-8361.

Kagkli, D. M.-Vancanneyt, M.-Vandamme, P.-Hill, C.-Cogan, T. M. (2007): Contamination of milk by enterococci and coliforms from bovine faeces. Journal of Applied Microbiology. 103. 1393-1405.

Korpysa-Dzirba, W.-Osek, J. (2011): Identification of genes encoding classical staphylococcal enterotoxins in Staphylococcus aureus isolated from raw milk. BulletinVeterinary Institute in Pulawy. 55. 1. 55-58

Mbuk, E. U.-Kwaga, J. K. P.-Bale, J. O. O.-Boro, L. A.-Umoh, J. U. (2016): Coliform organisms associated with milk of cows with mastitis and their sensitivity to commonly available antibiotics in Kaduna State, Nigeria. Journal of Veterinary Medicine and Animal Health. 8. 12. 228-236.

Mhone, T. A.-Matope, G.-Saidi, P. T. (2011): Aerobic bacterial, coliform, Escherichia coli and Staphylococcus aureus counts of raw and processed milk from selected smallholder dairy farms of Zimbabwe. International Journal of Food Microbiology. 151. 223-228.

MSZ EN ISO 4833-1 (2014): Az élelmiszerlánc mikrobiológiája. Horizontális módszer a mikroorganizmusok számlálására. 1. rész: Telepszámlálás $30^{\circ} \mathrm{C}$-on lemezöntés módszerrel.

MSZ EN ISO 6887-1 (2000): Élelmiszerek és takarmányok mikrobiológiája. A vizsgálati minták, az alapszuszpenzió és a decimális hígítások elkészítése mikrobiológiai vizsgálathoz. 1. rész: Az alapszuszpenzió és a decimális hígítások elkészítésének általános szabályai.

MSZ EN ISO 6888-1 (2008): Élelmiszerek és takarmányok mikrobiológiája. Horizontális módszer a koagulázpozitív sztafilokokkuszok (Staphylococcus aureus és más fajok) számának meghatározása. 1. rész: Baird-Parker-agar táptalajos eljárás.

Nóbrega, D. B.-Langoni, H. (2011): Breed and season influence on milk quality parameters and in mastitis occurrence. Pesquisa Veterinária Brasileira. 31. 12. 1045-1052.

Normanno, G.-La Salandra, G.-Dambrosio, A.-Quaglia, N. C.Corrente, M.-Parisi, A.-Santagada, G.-Firinu, A.-Crisetti, E.Celano, G. V (2007): Occurrence, characterization and antimicrobial resistance of enterotoxigenic Staphylococcus aureus isolated from meat and dairy products. International Journal of Food Microbiology. 115. 290-296.

Ózsvári, L.-Fux, A.-Illés, B. Cs.-Bíró, O. (2003): A Staphylococcus aureus tőgygyulladás által okozott gazdasági veszteségek számszerüsítése egy nagyüzemi holstein-fríz tehenészetben. Magyar Állatorvosok Lapja. 125. 579-584.

Paduch, J.-Mohr, E.-Krömker, V. (2012): The association between teat end hyperkeratosis and teat canal microbial load in lactating dairy cattle. Veterinary Microbiology. 158. 353-359.

Peles, F.-Máthéné, Sz. Zs.-Béri, B.-Szabó, A. (2008): A tartástechnológia hatása a nyers tej mikrobiológiai állapotára. Agrártudományi Közlemények. 31. 67-75.

Peles, F.-Wagner, M.-Keresztúri, P.-Béri, B.-Szabó, A. (2007): Staphylococcus aureus törzsek összehasonlító elemzése molekuláris mikrobiológiai módszerekkel. Agrártudományi Közlemények. 26. 34-39.

Peton, V.-Loir, Y. L. (2014): Staphylococcus aureus in veterinary medicine. Infection, Genetics and Evolution. 21. 602-615.

Pyörälä, S.-Taponen, S. (2009): Coagulase-negative staphylococciEmerging mastitis pathogens. Veterinary Microbiology. 134. 3 8.

Quigley, L.-O'Sullivan, O.-Beresford, T. P.-Ross, R. P.-Fitzgerald, G. F.-Cotter, P. D. (2011): Molecular approaches to analysing the microbial composition of raw milk and raw milk cheese. Review. International Journal of Food Microbiology. 150. 81-94.

Rompré, A.-Servais, P.-Baudart, J.-de-Roubin, M.-Laurent, P. (2002): Detection and enumeration of coliforms in drinking water: current methods and emerging approaches. Journal of Microbiological Methods. 49. 31-54.

Rosengren, Å.-Fabricius, A.-Guss, B.-Sylvén, S.-Lindqvist, R. (2010): Occurrence of foodborne pathogens and characterization of Staphylococcus aureus in cheese produced on farm-dairies. International Journal of Food Microbiology. 144. 263-269.

SPSS (2013): SPSS 22.0 for Windows. SPSS Inc., Chicago, IL, USA. Copyright @ SPSS Inc., 1989-2013. 
Tessema, F. (2016): Prevalence and Drug Resistance Patterns of Staphylococcus Aureus in Lactating Dairy Cow's Milk in Wolayta Sodo, Ethiopia. EC Veterinary Science. 2. 5. 226-230.

Tona, G. O.-Oladipo, I. C.-Oseni, S. O. (2016): Assessment of Physicochemical and Microbiological Quality of Jersey Cattle Raw Milk at Different Stages of Lactation. International Journal of Science and Research. 5. 6. 2610-2613.

Tortorello, M. L. (2003): Indicator Organisms for Safety and Quality-Uses and Methods for Detection: Minireview. Journal Of AOAC International. 86. 6. 1208-1217.

Tóth, T. (2015): A fejőberendezés és a tőgygyulladás kapcsolata. Holstein Magazin. 23. 1. 60-62.

Visciano, P.-Pomilio, F.-Tofalo, R.-Sacchini, L.-Saletti, M. A.Tieri, E.-Schirone, M.-Suzzi, G. (2014): Detection of methicillin-resistant Staphylococcus aureus in dairy cow farms. Food Control. 46. 532-538.
Waller, K. P.-Bengtsson, B.-Lindberg, A.-Nyman, A.-Unnerstad, H. E. (2009): Incidence of mastitis and bacterial findings at clinical mastitis in Swedish primiparous cows - Influence of breed and stage of lactation. Veterinary Microbiology. 134. 8994.

Zecconi, A.-Hamann, J.-Bronzo, V.-Ruffo, G. (2009): Machineinduced teat tissue reactions and infection risk in a dairy herd free from contagious mastitis pathogens. Journal of Dairy Research. 59. 3. 265-271. 
